\title{
Planktonic availability, molt stage and settlement of blue crab postlarvae
}

\author{
Romuald N. Lipcius, Eugene J. Olmi III, Jacques van Montfrans \\ The College of William and Mary, School of Marine Science, Virginia Institute of Marine Science, Gloucester Point, \\ Virginia 23062, USA
}

\begin{abstract}
We quantified (1) spatio-temporal variation in molt stage (developmental state) of blue crab Callinectes sapidus megalopae (postlarvae), and (2) the relationship between planktonic availability, molt stage and settlement of megalopae during peak settlement in Chesapeake Bay, USA. Settlement was significantly correlated with the planktonic availability of megalopae. Developmental state of megalopae also appeared influential in settlement because (1) blue crab megalopae displayed quantifiable changes in molt stage; (2) molt stage of megalopae varied on a temporal scale of days to 1 mo or more, and a spatial scale of kilometers, apparently reflecting the physiological progression through the molt cycle by megalopae pulsing through settlement habitats; and (3) molt stage of megalopae advanced in collections from the plankton, on artificial settlement habitats, and in the benthos, indicating the approach to settlement, metamorphosis and a benthic existence. In addition, settlement was not necessarily obligatory until sometime in late premolt, as many megalopae collected in the plankton were in late premolt. Hence, megalopae have the time in which to exercise some degree of habitat selection. Our findings show that settlement of a benthic invertebrate is regulated partly by the planktonic availability of postlarvae, and that these postlarvae progress through a predictable series of changes in developmental state as they invade settlement habitats. Thus, a quantitative measure of postlarval developmental state appears useful in relating planktonic availability of postlarvae to natural settlement patterns. Similar alterations in developmental state occur in the larval and postlarval stages of marine fish and a wide range of invertebrate taxa, indicating the potentially broad applicability of quantitative measures of developmental state in studies of settlement.
\end{abstract}

\section{INTRODUCTION}

Settlement rates of larvae or postlarvae, as constrained by planktonic availability (or supply rates sensu Roughgarden et al. 1988) may regulate recruitment patterns of many marine benthic invertebrates and demersal fish (Connell 1985, Butman 1987, Gaines \& Roughgarden 1987, Richards \& Lindeman 1987. Roughgarden et al. 1988). While settlement rates are affected by various factors (Herrnkind \& Butler 1986), a key influence is exerted through the likelihood of settlement in particular habitats, a process that generally changes with the developmental state of settling stages (Breder 1949, Ennis 1975, Marliave 1977. Botero \& Atema 1982, Cobb et al. 1983, Chia et al. 1984. Fukuhara 1985, 1988, Tanaka 1985, Butman 1987, Boehlert \& Mundy 1988). For instance, older postlarvae may be less selective in their habitat choices than younger postlarvae with a longer time before metamorphosis. Thus, in order to relate natural settlement rates to planktonic availability in these species, one must measure not only the abundance, but also the developmental state of potential settlers.

Despite the long-standing recognition that an interplay between habitat quality, developmental state and behavior determines settlement patterns in many species (e.g. delayed metamorphosis prior to settlement: Wilson 1952, Scheltema 1974), difficulties in quantifying behavioral, physiological and morphological features of planktonic larvae and postlarvae in nature have precluded comprehensive measurements relating developmental state and behavior to settlement (Connell 1985, Butman 1987. Richards \& Lindeman 1987). We provide quantitative field measurements of developmental state for settlement pulses of the blue crab Callinectes sapidus Rathbun, demonstrating (1) patterns and variation over space and time; (2) a significant correlation of settlement with the planktonic availability of recruiting postlarvae; and (3) a potential association between the developmental state of planktonic postlarvae and settlement. 


\section{RECRUITMENT AND SETTLEMENT PROCESSES IN CALLINECTES SAPIDUS}

The blue crab is a dominant benthic marine invertebrate of shallow coastal and estuarine habitats in the Northwest Atlantic, Gulf of Mexico and Caribbean (Williams 1984). In Chesapeake Bay (USA), mature females release larvae near the mouth of the bay from June through September (Van Engel 1958). Seaward currents transport the early-stage larvae to continental shelf waters, where development proceeds through 7 or 8 larval stages (Costlow 1967, McConaugha et al. 1983). In the continental shelf waters the larvae metamorphose into a postlarval stage, the megalopa, whose behavior, morphology and physiology are transitional between larval and early juvenile stages (Cronin \& Forward 1982, Sulkin \& Van Heukelem 1986). Megalopae may use episodic wind-driven surface currents (Johnson et al. 1984, Goodrich et al. 1989), predictable on-shore deep residual currents (Sulkin \& Epifanio 1986), internal waves (Shanks 1983, 1985, 1988), or a combination of these systems (Sulkin \& Van Heukelem 1986) to remain near the Chesapeake Bay mouth and subsequently reinvade shallow estuarine settlement habitats.

In the blue crab, we define recruitment as the immigration of larvae, megalopae (postlarvae) or young juveniles into estuarine nursery habitats. Settlement is defined as the temporary or permanent adoption of a benthic existence by megalopae or young juvenile stages in the benthos or on artificial settlement habitats (van Montfrans et al. 1990). Settlement on artificial settlement habitats is an active process, and not merely due to passive filtering of potential settlers (i.e. megalopae and young juveniles) because these stages are active swimmers capable of leaving artificial and natural settlement habitats (Cronin \& Forward 1982, Sulkin \& Van Heukelem 1986).

After reinvasion of Chesapeake Bay, megalopae enter shallow potential settlement sites (e.g. seagrass beds) in pulses on flood tides (E. J. Olmi III unpubl.) around the new or full moon from July through November (van Montfrans et al. 1990). Such episodic events control the large-scale availability of potential settlers, but planktonic availability of potential settlers does not completely determine megalopal settlement patterns in space or time (Olmi et al. 1990). We postulated that the low correlation between planktonic availability of megalopae and settlement was partially a consequence of organismal processes (e.g. physiological readiness to settle). Therefore, we quantified spatial and temporal variation in the developmental state of megalopae with a multi-factorial sampling design during major settlement pulses in Chesapeake Bay In particular, we examined: (1) development state of planktonic megalopae over spatial and temporal scales relevant to settlement pulses in the York River system of Chesapeake Bay; and (2) developmental state of megalopae in the plankton, on artificial settlement habitats, and in the benthos, where natural settlement occurs

\section{STUDY SITES}

Megalopal sampling was conducted at 2 geographic locations within the York River system $\left(37^{\circ} 17.45^{\prime} \mathrm{N}\right.$, $76^{\circ} 22.65^{\prime} \mathrm{W}$ ) of Chesapeake Bay. One is located near the mouth of the York River, and contains extensive eelgrass Zostera marina and widgeongrass Ruppia maritima beds, the primary settlement habitat (Orth \& van Montfrans 1987). The other location is $12 \mathrm{~km}$ upriver, also contains eelgrass beds, and is known for major pulses of megalopae and young juvenile blue crabs in the plankton and benthos (Olmi et al. 1990), and on artificial settlement habitats (van Montfrans et al. 1990).

Although the sampling scheme differed on the 3 dates, we sampled 2 sites each at the upriver and mouth locations on $9 / 10$ September, 6/7 October and 8/9 October 1987. One set of sites at the river mouth location (Mobjack Bay) was sampled on 9/10 September 1987. but abandoned after the September samples due to weak tidal currents. Another set of sites at the river mouth location (Allen's Island) was sampled on both dates in October. A third set of sites, which served as the sites for the upriver location (Virginia Institute of Marine Science area), was sampled on all 3 dates.

\section{MATERIALS AND METHODS}

Megalopal sampling. Megalopae recruit and settle primarily during nocturnal flood tides (Meredith 1982, E. J Olmi III unpubl.). Hence our sampling for megalopae encompassed one night each on $9 / 10 \mathrm{Sep}-$ tember, 6/7 October and 8/9 October 1987 in the plankton, on artificial settlement habitats, and in seagrass beds (natural settlement habitat). Collections from the plankton provided information on megalopal availability; those from artificial settlement habitats on relative settlement rates; and those from seagrass beds on natural settlement rates. Olmi et al. (1990) provide a detailed description of sampling methods; a synopsis follows.

Paired plankton nets were fished at 2 sites in each upriver and mouth location for 20 min during maximum nocturnal flood tides, when most megalopal recruit ment occurs (Meredith 1982, E. J. Olmi III unpubl.). Each net (mesh $=750 \mu \mathrm{m})$ filtered an area $50 \mathrm{~cm}$ wide 
from the surface of the water to a depth of $80 \mathrm{~cm}$; nets were $1 \mathrm{~m}$ apart. All plankton samples were standardized to water flow by attached current meters (General Oceanics model 2030).

Artificial settlement habitats were synthetic fiber ('hog's hair') air conditioning filters $(47 \times 39 \times 1 \mathrm{~cm})$, which have been used for monitoring relative settlement rates of megalopae since 1985 (van Montfrans et al. 1990). Four artificial habitats were deployed vertically $15 \mathrm{~cm}$ below the surface at each site prior to sunset on 9 September, 6 October and 8 October and retrieved the following mornings; all settled megalopae were then enumerated. Megalopae taken from the 4 artificial habitats per site were used to provide a single sample for molt staging, thereby providing 2 replicate samples (i.e. 2 sites) at each location.

Benthic megalopae were sampled in the seagrass beds using screened cylindrical $0.055 \mathrm{~m}^{2}$ frames and a suction sampler (Orth \& van Montfrans 1987). Samples were collected at each site on the mornings following deployment of artificial habitats and collection of plankton samples.

Molt stage (developmental state) determination. The megalopal stage generally lasts 20 to $40 \mathrm{~d}$ (Sulkin \& Van Heukelem 1986), and encompasses differing behavioral and physiological phases prior to settlement and metamorphosis to the first crab. After metamorphosis from the last larval (zoeal) stage, megalopae progress through a series of morphological changes during the molt cycle (metamorphosis to megalopa postmolt - intermolt - premolt - metamorphosis to first juvenile instar). These alterations are evident morphologically in the setae and cuticle, and behaviorally in the enhancement of activities promoting settlement (e.g. negative phototaxis) as the megalopae approach metamorphosis to the first juvenile instar (Sulkin \& Van Heukelem 1986).

We quantified developmental state (i.e. molt stage) in uropods of live, recently-collected megalopae. The use of live specimens is more reliable than preserved specimens (in alcohol or formaldehyde) because preservation can artificially alter epidermal structure (Buchholz 1982, Anger 1983). Specifically, individual uropods were examined under a dissecting or compound microscope, and staged as to molt phase according to documented morphological criteria (Aiken 1973): intermolt (molt stage C), early premolt (molt stages $\mathrm{D}_{0}$ through $\mathrm{D}_{0,2.0}$ ), or late premolt (molt stages $\mathrm{D}_{0,2.5}$ through ecdysis). We did not detect any postmolt individuals since the postmolt phase is brief (1 to $4 \mathrm{~d}$ : Anger 1983, Hatfield 1983) and the megalopae collected in the York River system had likely metamorphosed from the last zoeal stage 1 to 3 wk earlier off the mouth of Chesapeake Bay (McConaugha 1988). Similar techniques have been employed in molt-stage determinations with megalopae of other crabs, including the spider crab Hyas araneus (Anger 1983) and the Dungeness crab Cancer magister (Hatfield 1983).

The relationship between molt stage and the time to metamorphosis was examined by selecting groups of megalopae in different molt stages and recording their time to metamorphosis into the first juvenile instar in laboratory cultures at $26^{\circ} \mathrm{C}\left( \pm 2{ }^{\circ} \mathrm{C}\right)$ and $21 \mathrm{ppt}$ salinity. Intermolt megalopae took significantly longer to metamorphose $($ mean $=69.4 \mathrm{~h}, \mathrm{SD}=18.9, \mathrm{n}=4)$ than premolt individuals (mean $=24.9 \mathrm{~h}, \mathrm{SD}=22.6, \mathrm{n}=14$; t-test, $\mathrm{p}<0.05)$. Hence, molt stage is an objective indicator of the proximity to metamorphosis in blue crab megalopae.

Experimental design and statistical analysis. Statistical analyses were conducted on molt-stage frequencies (log-likelihood analysis: Sokal \& Rohlf 1981), or proportions (ANOVA) which were arc-sine square-root transformed when required to meet assumptions of normality and homogeneity of variance (Sokal \& Rohlf 1981, Underwood 1981). In all cases, either variances were homogeneous, or the statistical test rejected the null hypothesis at a significance level lower than that of the test for homogeneity of variances (Underwood 1981).

The following factors and variables were used in statistical analyses: (1) Geographic location as a 2-level factor encompassing one location near the mouth of the York River and a second one upriver; (2) Day as a 2level factor corresponding to $6 / 7$ and $8 / 9$ October 1987 [the samples collected on 9/10 September 1987 could not be used in the Day comparison with the October samples because of the confounding effect (sensu Hurlbert 1984) of monthly variation]; (3) Habitat as a 3-level factor including the plankton, artificial habitats and benthos; (4) Planktonic abundance of megalopae as a covariate; (5) Molt stage as a dependent variable or covariate with either the proportions (ANOVA) or frequencies (log-likelihood analysis) of intermolt and premolt megalopae as the analysed values; and (6) Settlement as a dependent variable measured by the numbers of megalopae on artificial settlement habitats or in the benthos. The data sets used to test particular hypotheses differed, and are described below.

Spatial and temporal variation in molt stage of planktonic megalopae. Spatial and temporal variation was examined with ANOVA (Factors: Geographic location and Day) on molt stage proportions of megalopae in the plankton on 6/7 and 8/9 October. The proportions of intermolt (or premolt - the sum of both premolt categories) megalopae were sampled twice (i.e. 2 sites) on each date at each location, providing an orthogonal, balanced design with 8 treatment combinations ( 2 days $\times 2$ locations $\times 2$ sites). Proportions were calculated from 10 to 20 megalopae per sample. 
Molt stage of megalopae from the plankton, artificial settlement habitats and benthos. Equivalent samples were available to compare molt stage frequencies (intermolt, early premolt and late premolt) by habitat on 9/10 September and 8/9 October. Separate 3-way log-likelihood analyses were employed each date with Habitat, Location/site and Molt stage. We did not use ANOVA because of the incomplete replication of sites at all locations. During September, each habitat was sampled twice (2 sites) at the upriver location. During October $8 / 9$, habitats were sampled once at both the mouth and upriver locations. In both analyses the Location/site factor was non-significant, precluding a problem in interpretation due to confounding of location and site effects

The use of log-likelihood analyses assumes independence between individual megalopae. Planktonic and benthic megalopae were sparsely distributed in their natural habitats and together in the sampling apparatus for a relatively short time, thereby precluding non-independence in physiological state between individuals. Megalopae from artificial settlement habitats were potentially interacting throughout the nocturnal sampling period, and therefore possibly nonindependent in physiological state. Thus, we used an F-test to compare the variances within each Habitat and Location/site combination to the binomial variances expected if each individual were behaving independently. When significant departures were found, the significance levels were adjusted to provide a conservative test of habitat effects. In all cases (including megalopae from the plankton, benthos and artificial settlement habitats), either the F-tests of the variance ratio were non-significant, or the log-likelihood test remained significant with the adjusted significance levels (set at an experimentwise error rate of 0.05 ). See Peterson (1982, p. 454-455) for a detailed description of this method.

Relationship between planktonic availability, molt stage and settlement of megalopae. The number of settled megalopae on artificial settlement habitats and in the benthos was correlated with (1) the proportion of premolt megalopae in the plankton and (2) the abundance of planktonic megalopae. Values were derived from 8 site-specific samples on $6 / 7$ and $8 / 9$ October. 2 sites each from the mouth and upriver locations (2 days $\times 2$ locations $\times 2$ sites). Molt stage proportions were based on 10 to 20 megalopae per sample. The analysis employed ANCOVA with day and location as factors, and the proportion of premolt megalopae or abundance of planktonic megalopae as the covariates. The final analysis met assumptions of homogeneity of slopes and variances. Residuals were examined for non-random patterns and deviation from parametric assumptions (Draper \& Smith 1981).

\section{RESULTS}

\section{Spatial and temporal variation in molt stage of planktonic megalopae}

The proportions of premolt megalopae in the plankton differed significantly by geographic location and day of collection (Fig. 1; ANOVA: for Day: $F=8.64, p=0.042$, $\mathrm{df}=1,4$; Geographiclocation: $\mathrm{F}=12.07, \mathrm{p}=0.025 \mathrm{df}=$ $1,4)$. The Location $\times$ Day interaction effect was not significant $(p>0.05)$. There were significantly more premolt megalopae near the upriver location in the York River, indicating advancement through the molt cycle as the megalopae moved from the mouth to upriver locations (Fig. 1). The proportion of premolt megalopae also increased significantly over the $2 \mathrm{~d}$ sampling period, with higher proportions of developmentally advanced (i.e. premolt) megalopae on the second day (Fig. 1). This result is consistent with an episodic ingress of megalopae into the York River 1 to $3 \mathrm{~d}$ before the October sampling period, and its progression upriver as the megalopae advanced through the molt cycle and encountered potential settlement habitats.

\section{Molt stages of megalopae from the plankton, artificial settlement habitats and benthos}

During the 9/10 September and 8/9 October sampling dates, molt stage frequencies differed significantly by habitat, but not by location/site (Tables 1 and 2). Most planktonic megalopae were in intermolt or early premolt (Fig. 2a, d), and significantly less advanced in molt stage than megalopae in the benthos on both sampling dates (Fig. 2c, $\mathrm{f}_{\text {; }}$ Tables 1 and 2). Most megalopae collected in the benthos - natural settle-

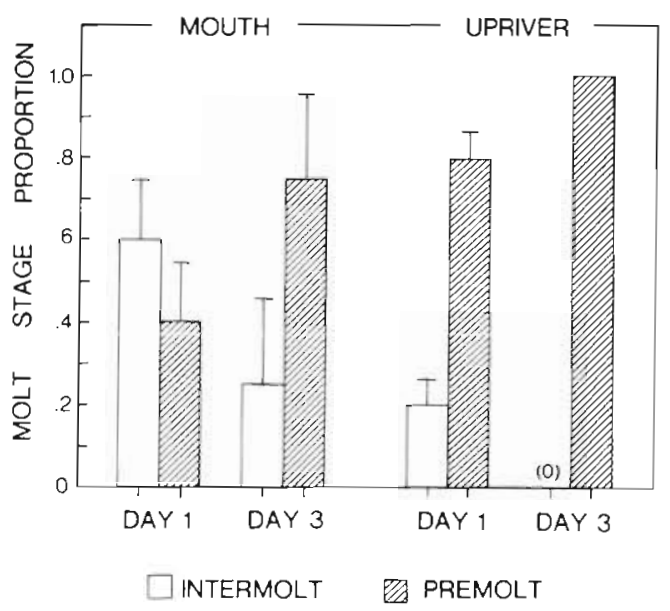

Fig. 1. Callnectes sapidus. Molt-stage proportions of blue crab megalopae collected in the plankton on 6/7 October (Day 1) and 8/9 October (Day 2), 1987 at 2 sites each near the mouth of the York River and upriver There were no intermolt megalopae on $8 / 9$ October 1987 at the upriver location. Vertical bars denote standard deviations 
Table 1 Callinectes sapidus. Log-likelihood analysis of variance results for habitat and location/site (noted as Site) effects upon the frequencies of intermolt, early premolt and late premolt megalopae during $9 / 10$ September 1987 (Fig. 2a to c). Significance levels for the paired comparisons are set at an experimentwise error rate of $0.05, p<0.05, \cdots p<0.01, \cdots p<0.005$

\begin{tabular}{|c|c|c|c|c|}
\hline Habitats & Source of variation & $\mathrm{df}$ & $\mathrm{G}$ & Significance \\
\hline All & $\begin{array}{c}\text { Habitat } \\
\text { Site }\end{array}$ & $\begin{array}{l}4 \\
2\end{array}$ & $\begin{array}{r}14.92 \\
0.34\end{array}$ & $\begin{array}{l}\cdots \\
\mathrm{ns}\end{array}$ \\
\hline Plankton vs Substrates & $\begin{array}{l}\text { Habitat } \\
\text { Site }\end{array}$ & $\begin{array}{l}2 \\
2\end{array}$ & $\begin{array}{l}4.95 \\
0.34\end{array}$ & $\begin{array}{l}\text { ns } \\
\text { ns }\end{array}$ \\
\hline Plankton vs Benthos & $\begin{array}{c}\text { Habitat } \\
\text { Site }\end{array}$ & $\begin{array}{l}2 \\
2\end{array}$ & $\begin{array}{r}12.89 \\
1.20\end{array}$ & $\begin{array}{l}\cdots \\
\text { ns }\end{array}$ \\
\hline Substrates vs Benthos & $\begin{array}{c}\text { Habitat } \\
\text { Site }\end{array}$ & $\begin{array}{l}2 \\
2\end{array}$ & $\begin{array}{l}5.99 \\
0.13\end{array}$ & $\begin{array}{l}\text { ns } \\
\text { ns }\end{array}$ \\
\hline
\end{tabular}

Table 2. Callinectes sapidus. Log-likelihood analysis of variance results for habitat and location/site (noted as Site) effects upon the frequencies of intermolt, early premolt and late premolt megalopae during 8/9 October 1987 (Fig. $2 \mathrm{~d}$ to f). Significance levels for the paired comparisons are set at an experimentwise error rate of $0.05 \cdot p<0.05, \cdots p<0.01, \cdots p<0.005$

\begin{tabular}{|c|c|c|c|c|}
\hline Habitats & Source of variation & $d f$ & $G$ & Significance \\
\hline All & $\begin{array}{l}\text { Habitat } \\
\text { Site }\end{array}$ & $\begin{array}{l}4 \\
2\end{array}$ & $\begin{array}{r}11.95 \\
1.11\end{array}$ & ' \\
\hline Plankton vs Substrates & $\begin{array}{l}\text { Habitat } \\
\text { Site }\end{array}$ & $\begin{array}{l}2 \\
2\end{array}$ & $\begin{array}{l}1.62 \\
1.66\end{array}$ & $\begin{array}{l}\text { ns } \\
\text { ns }\end{array}$ \\
\hline Plankton vs Benthos & $\begin{array}{l}\text { Habitat } \\
\text { Site }\end{array}$ & $\begin{array}{l}2 \\
2\end{array}$ & $\begin{array}{r}11.54 \\
1.96\end{array}$ & $\ddot{n s}$ \\
\hline Substrates vs Benthos & $\begin{array}{c}\text { Habitat } \\
\text { Site }\end{array}$ & $\begin{array}{l}2 \\
2\end{array}$ & $\begin{array}{l}5.10 \\
0.01\end{array}$ & $\begin{array}{l}\text { ns } \\
\text { ns }\end{array}$ \\
\hline
\end{tabular}

ment habitat - were in late premolt (Fig. 2c, f), and rapidly approaching metamorphosis to the first juvenile instar. Megalopae on artificial settlement habitats had entered premolt, with a significant number in late premolt (Fig. 2b, e). Though these megalopae were in an intermediate developmental state between planktonic and benthic megalopae, they did not differ significantly in molt stage from the others (Tables 1 and 2).

\section{Relationship between planktonic availability, molt} stage and settlement of megalopae

Megalopal settlement on artificial settlement substrates and in the benthos was significantly and positively correlated with the abundance of planktonic megalopae (Fig. 3a), with higher settlement on the second sampling day in October (ANCOVA: For Day: $\mathrm{F}=15.27, \mathrm{p}=0.030, \mathrm{df}=1,3$; Location: $\mathrm{F}=0.27, \mathrm{p}=$ $0.641, d=1,3$; covariate-planktonic abundance: $F=$ 10.27, $\mathrm{p}=0.049, \mathrm{df}=1,3$ ). Postlarval settlement was not significantly correlated at the 0.05 level with the proportion of premolt megalopae in the plankton, though the data suggested a positive relationship that was obscured due to low sample sizes (Fig. 3b)

\section{DISCUSSION}

Recruitment variation, which can drive population fluctuations in marine organisms, is at times reflected in the settlement patterns of benthic species (Connell 1985, Butman 1987, Richards \& Lindeman 1987, Roughgarden et al. 1988). Our field results indicate that settlement by postlarvae (megalopae) of a dominant marine benthic invertebrate, the blue crab, is governed by the planktonic availability of megalopae, and also may be influenced by the molt stage (developmental state) of recruiting megalopae. The latter inference stems from the findings that: (1) blue crab megalopae displayed quantifiable differences in molt stage; (2) molt stage of megalopae varied on a temporal scale of days to 1 mo or more, and a spatial scale of kilometers, apparently reflecting the physiological progression through the molt cycle by megalopae pulsing through an estuarine settlement habitat; and (3) molt stage of megalopae advanced in collections from the plankton, on artificial settlement habitats, and in the benthos, indicating the approach to settlement, metamorphosis and a benthic existence.

Blue crab megalopae appear to progress through a 

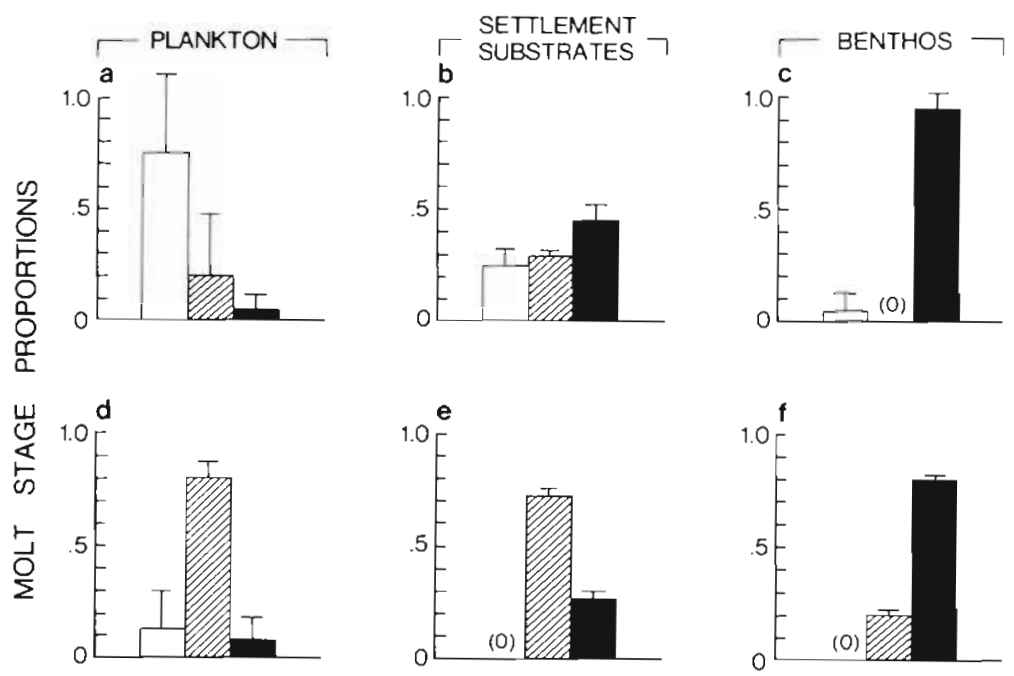

INTERMOLT

EARLY PREMOLT
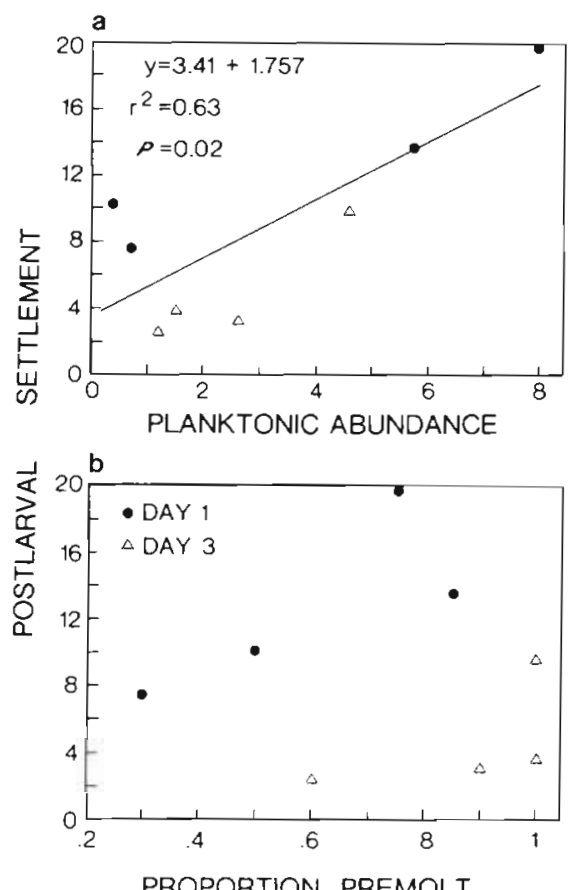

Fig. 3. Callinectes sapidus. Relationship between postlarval settlement (mean number of megalopae per collector and benthic samplej and (a) planktonic abundance of megalopae (mean number of megalopae per $10 \mathrm{~m}^{3}$ ) or (b) mean proportion of premolt megalopae in the plankton. The 2 highest settlement values on each day are from the upriver location. The regression line is drawn jointly for both days to facilitate visual inspection

predictable series of developmental and behavioral alterations as they reinvade estuarine settlement habitats. The developmental series proceeds from metamorphosis (molting) to the megalopal stage; through the postmolt, intermolt and premolt phases;
Fig. 2. Callinectes sapidus. Molt-stage proportions of megalopae collected in 3 habitats: benthos (natural settlement habitat), artificial settlement habitats (substrates) and plankton on (a to c) $9 / 10$ September and (d to f) $8 / 9$ October, 1987 near the mouth of the York River and upriver. Absence of benthic megalopae from the benthos on $6 / 7$ October 1987 precluded analyses for that date. Vertical bars denote standard deviations

and metamorphosis to the first juvenile crab instar. The behavioral progression most likely involves a transition from behaviors that promote retention near the surface in young megalopae (e.g. negative geotaxis, positive phototaxis and high barokinesis) to those that may induce a benthic habit in older megalopae (e.g. reduced locomotory activity, negative phototaxis, positive geotaxis and high thigmokinesis; see Sulkin 1984 , Sulkin \& Van Heukelem 1986 for examples and details). We postulate that newly metamorphosed megalopae on the continental shelf advance rapidly through postmolt and enter intermolt as they are advected towards the Chesapeake Bay mouth. Consistent with this hypothesis, megalopae that were in early premolt off the Bay mouth (McConaugha 1988: Fig. 7) took approximately equal time to metamorphose to the first juvenile instar as those in our study that we determined to be in intermolt or early premolt. Once megalopae reinvade shallow estuarine habitats (e.g. grassbeds), they are in more advanced developmental stages ranging from late intermolt through late premolt. These megalopae come in contact with seagrass beds, which appear to be the primary settlement habitat (Orth \& van Montfrans 1987, van Montfrans et al. 1990). There they can initiate habitat evaluation by vertical migrations between the surface and bottom (Sulkin \& Van Heukelem 1986). It is during this phase that the molt stage of megalopae may influence habitat choice or the likelihood of settlement.

Settlement was not necessarily obligatory until sometime in late premolt, as many megalopae collected in the plankton were in late premolt. Thus, megalopae have the time in which to exercise some degree of habitat selection, possibly depending upon local hy- 
drodynamics and habitat features (e.g. habitat architecture: Herrnkind \& Butler 1986). Moreover, newly metamorphosed juveniles can re-enter the water column (Meredith 1982, Olmi et al. 1990) and migrate to other, more suitable habitats.

Given: (1) the differences in time to metamorphosis of megalopae differing by molt stage; (2) documented behavioral changes in megalopae whereby activities promoting settlement increase in frequency as megalopae develop (Sulkin \& Van Heukelem 1986); and (3) the natural progression from intermolt to premolt as megalopae develop, we suggest that molt stage (i.e. developmental state) may influence the likelihood of megalopal settlement. Alternately, the developmental state of megalopae may merely advance as the megalopae age while immigrating to nursery habitats, and affect neither the timing nor location of settlement. Experimental tests are needed to verify either hypothesis or other alternatives.

Our findings show that settlement of a benthic invertebrate is regulated partly by the planktonic availability of postlarvae, and that these postlarvae progress through a predictable series of changes in developmental state as they invade settlement habitats. Thus, a quantitative measure of postlarval developmental state appears useful in relating planktonic availability of recruits (supply of postlarvae) to natural settlement patterns. Similar alterations in developmental state occur in the larval and postlarval stages of marine fish and a wide range of invertebrate taxa (Breder 1949, Ennis 1975, Marliave 1977, Botero \& Atema 1982, Cobb et al. 1983, Chia et al. 1984, Fukuhara 1985, 1988, Tanaka 1985, Butman 1987, Boehlert \& Mundy 1988), indicating the potentially broad applicability of quantitative measures of developmental state in studies of marine recruitment.

Acknowledgements. We thank S. Gaines, W. Herrnkind, E. Houde, M. Luckenbach, J. Olney, R. Orth, C. Peterson, W. Van Engel and 2 anonymous referees for reviews; D. Eggleston, R Mansour, L. Marshall, Jr, C. Peery and P. Sadler for technical assistance; the Commonwealth of Virginia, Virginia Sea Grant (NA 86 AA-D-SG 042), National Science Foundation (OCE $87-$ 00414) and W. A. Van Engel Fellowship Program for financial support. Contribution No. 1561 of the Virginia Institute of Marine Science.

\section{LITERATURE CITED}

Aiken, D. E. (1973). Proecdysis, setal development, and molt prediction in the American lobster (Homarus americanus). J. Fish. Res. Bd Can. 30: 1337-1344

Anger, K. (1983). Moult cycle and morphogenesis in Hyas araneus larvae (Decapoda, Majidae), reared in the laboratory. Helgoländer Meersunters. 36: 285-302

Boehlert, G. W., Mundy, B. C. (1988). The role of behavioral and physical factors in larval and juvenile fish recruitment to estuarine nursery areas. Am. Fish. Soc. Symp. 3: 51-67
Botero, L., Atema, J. (1982). Behavior and substrate selection during larval settling in the lobster Homarus americanus. J. Crust. Biol. 2: 59-69

Breder, Jr, C. M. (1949). On the taxonomy and the postlarval stages of the surgeonfish, Acanthurus hepatus. Copeia 1949: 296

Buchholz, F. (1982). Drach's molt staging system adapted for euphausiids. Mar Biol. 66: 301-305

Butman, C. A (1987). Larval settlement of soft-sediment invertebrates: the spatial scales of pattern explained by active habitat selection and the emerging role of hydrodynamical processes. Oceanogr. mar. Biol. A. Rev. 25: $113-165$

Chia, F.-S., Buckland-Nicks, J., Young, C. M. (1984). Locomotion of marine invertebrate larvae: a review. Can. J. Zool. 62: $1205-1222$

Cobb, J. S., Gulbransen, T., Phillips, B. F., Wang, D., Syslo, M. (1983). Behavior and distribution of larval and early juvenile Homarus americanus. Can. J. Fish. Aquat. Sci. 40 $2184-2188$

Connell, J. H. (1985). The consequences of variation in initial settlement vs post-settlement mortality in rocky intertidal communities. J. exp. mar Biol. Ecol. 93: 11-45

Costlow, J. D. Jr (1967). The effect of salinity and temperature on survival and metamorphosis of megalops of the blue crab Callinectes sapidus. Helgoländer wiss. Meeresunters. 15: $84-97$

Cronin, T. W., Forward, R. B. (1982). Tidally timed behavior effects on larval distributions in estuaries. In: Kennedy, V S. (ed.) Estuarine comparisons. Academic Press, New York, p. 505-520

Draper, N. R., Smith, H. (1981). Applied regression analysis Wiley \& Sons, New York

Ennis, G. P. (1975). Behavioral responses to changes in hydrostatic pressure and light during larval development of the lobster Homarus americanus. J. Fish. Res. Bd Can. 32: $271-281$

Fukuhara, O. (1985). Functional morphology and behavior of early life stages of red sea bream. Bull. Jap. Soc. scient. Fish. 51 731-743

Fukuhara, O. (1988). Morphological and functional development of larval and juvenile Limanda yokohamae (Pisces: Pleuronectidae) reared in the laboratory. Mar. Biol. 99: $271-281$

Gaines, S. D., Roughgarden, J. (1987). Fish in offshore kelp forests affect recruitment to intertidal barnacle populations. Science 235: 479-481

Goodrich, D. M., van Montfrans, J., Orth, R. J. (1989). Blue crab megalopal influx to Chesapeake Bay: evidence for a wind-driven mechanism. Estuar. cstl Shelf Sci. 29: in press

Hatfield, S. E. (1983). Intermolt staging and distribution of Dungeness crab, Cancer magister, megalopae. Calif. Dep. Fish Game Fish. Bull. 172: 85-96

Herrnkind, W. F., Butler, M. J., IV (1986). Factors regulating postlarval settlement and juvenile microhabitat use by spiny lobsters Panulirus argus. Mar. Ecol. Prog. Ser 34: 23-30

Hurlbert, S. H. (1984). Pseudoreplication and the design of ecological field experiments. Ecol. Monogr, 54: 187-211

Johnson, D. R., Hester, B. S., McConaugha, J. R. (1984). Studies of a wind mechanism influencing the recruitment of blue crabs in the Middle Atlantic Bight. Cont. Shelf Res. 3: $425-437$

Marliave, J. B. (1977). Substratum preferences of settling larvae of marine fishes reared in the laboratory. J, exp. mar. Biol. Ecol. 27: 47-60

McConaugha, J. R. (1988). Export and reinvasion of larvae as 
regulators of estuarine decapod populations. Am. Fish Soc. Symp. 3: 90-103

McConaugha, J. R., Johnson, D. F., Provenzano, A. J., Maris, R. C. (1983). Seasonal distribution of larvae of Callinectes sapidus (Crustacea: Decapoda) in the waters adjacent to Chesapeake Bay. J. Crust. Biol. 3: 582-591

Meredith. W. H. (1982). The dynamics of zooplankton and micronekton community structure across a salt marshestuarine waters interface of lower Delaware Bay. Ph. D. dissertation, University of Delaware

Olmi, E. J., III, van Montfrans, J., Lipcius, R. N., Orth, R. J., Sadler, P. (1990). Variation in planktonic availability and settlement of blue crab megalopae in the York River, Virginia. Bull. mar Sci. 46: in press

Orth, R. J, van Montfrans, J. (1987). Utilization of a seagrass meadow and tidal marsh creek by blue crabs Callinectes sapidus. I. Seasonal and annual variations in abundance with emphasis on post-settlement juveniles. Mar Ecol. Prog. Ser. 41: 283-294

Peterson, C. P. (1982). The importance of predation and intraand interspecific competition in the population biology of two infaunal suspension-feeding bivalves, Protothaca staminea and Chione undatella. Ecol. Monogr. 52:437-475

Richards, W. J., Lindeman, K. C. (1987). Recruitment dynamics of reef fishes: planktonic processes, settlement and demersal ecologies, and fishery analysis. Bull. mar. Sci 41. 392-410

Roughgarden, J., Gaines, S., Possingham, H. (1988). Recruitment dynamics in complex life cycles. Science 241 $1460-1466$

Scheltema, R. S. (1974). Biological interactions determining larval settlement of marine invertebrates. Thalassia jugosl. 10: $263-296$

Shanks, A. L. (1983). Surface slicks associated with tidally forced internal waves may transport pelagic larvae of benthic invertebrates and fishes shoreward. Mar Ecol. Prog. Ser. 13: 311-315

Shanks, A. L. (1985). Behavioral basis of internal-waveinduced shoreward transport of megalopae of the crab Pachygrapsus crassipes. Mar Ecol. Prog. Ser. 24. 289-295

This article was presented by Professor C. H. Peterson, Morehead City, N. Carolina, USA
Shanks, A. L. (1988). Further support for the hypothesis that internal waves can cause shoreward transport of larval invertebrates and fish. Fish. Bull. U.S. 86: 703-714

Sokal, R. R., Rohlf, F. J. (1981). Biometry. W. H. Freeman, New York

Sulkin, S. D. (1984). Behavioral basis of depth regulation in the larvae of brachyuran crabs. Mar Ecol. Prog. Ser. 15: $181-205$

Sulkin, S. D., Epifanio, C. E. (1986). Natural regulation of juvenile recruitment in the blue crab (Callinectes sapidus Rathbun) and its consequences for sampling and management strategy. Spec. Publs Can. Fish. Aquat. Sci. 92: $117-123$

Sulkin, S. D., Van Heukelem, W F. (1986). Variability in the length of the megalopal stage and its consequence to dispersal and recruitment in the portunid crab Callinectes sapidus Rathbun. Bull. mar. Sci. 39: 269-278

Tanaka, M. (1985). Inshore migration process into the nursery ground with the transition from pelagic larvae to demersal juveniles in the red sea bream, Pagrus major (Temminck et Schlegel). Trans. Am. Fish. Soc. 114:471-477

Underwood, A. J. (1981). Techniques of analysis of variance in experimental marine biology and ecology. Oceanogr. mar. Biol. A. Rev. 19: 513-605

Van Engel, W. A. (1958). The blue crab and its fishery in Chesapeake Bay. Part 1 - Reproduction, early development, growth and migration. Cormml Fish. Rev. 20: 6-17

van Montfrans, J., Peery, C., Orth, R. J. (1990). Daily, monthly and annual settlement patterns by Callinectes sapidus and Neopanope sayi megalopae on artificial collectors deployed in the York River, Virginia: 1985-1988. Bull. mar. Sci. 46 : in press

Williams, A. B. (1984). Shrimps, lobsters, and crabs of the Atlantic Coast of the Eastern United States, Maine to Florida. Smithsonian Institution, Washington, D.C.

Wilson, D. P. (1952). The influence of the nature of the substratum on the metamorphosis of the larvae of marine animals, especially the larvae of Ophelia bicornis Savigny. Annls Inst. Océanogr Monaco 27: 49-156

Manuscript first received: March 28, 1989

Revised version accepted: August 18, 1989 